\title{
Palaeoenvironmental Background and Age of the Late Palaeolithic Settlement in SE Poland (A Case Study from the Sandomierz Upland and Carpathians)
}

\author{
Maryna Komar ${ }^{*}$, Lanczont Maria $^{2}$, Valde-Nowak Paweł ${ }^{3}$, Bałaga Krystyna ${ }^{2}$, Hołub Beata ${ }^{2}$, \\ Kusiak Jarosław ${ }^{2}$, Mroczek Przemysław ${ }^{2}$ and Zieliński Paweł ${ }^{2}$ \\ ${ }^{I}$ Institute of Geological Sciences, National Academy of Sciences of Ukraine, O. Gonchar str. 55-b, 01054, Kyiv, Ukraine \\ ${ }^{2}$ Institute of Earth Sciences, Maria Curie-Skłodowska University, Al. Kraśnicka 2 cd, 20-817 Lublin, Poland \\ ${ }^{3}$ Institute of Archaeology, Jagiellonian University, Gołębia 11, str. 31-007 Cracow, Poland
}

\begin{abstract}
The aim of the natural investigations carried out in two archaeological sites in the SE Poland was to determine their TL age (15 samples) and characterize the vegetation cover with the use of pollen analysis (10 samples) of loess and loess-like deposits sampled in the sites and their close environs. Micromorphological features of loess were examined in one of the sites. The research was carried out in a Late Magdalenian site near Wilczyce village in the eastern part of the Sandomierz Upland, and in a Final Palaeolithic site, with the Świdry Culture materials, near of Mucharz village in the eastern margin of the Small Beskid Mts, flysch Outer Carpathians. Both sites are situated in the Vistula River basin (mountain and upland section), in immediate vicinity of river valleys, i.e. Opatówka and Skawa River, respectively. They are located on high riverbanks, in exposed places that were good observation points. The Magdalenian site was TL dated at about $15 \mathrm{ka}$ BP that corresponds well with the results of radiocarbon dating. The site was surrounded by a mosaic of different vegetation typical of quite cold climate habitats: wet tundra communities, dry steppe with xerophytes, and patches of coniferous trees. The TL dates obtained for the site with the Świdry Culture materials ranged from 10.3 to 11.02 ka BP (Dryas III). Tundra communities with Selaginella s. occurred in park-type landscape but the vegetation succession changed after settlement retreat. Coniferous forests with an admixture of birch, next hazel (macroremnants) and alder developed.
\end{abstract}

Keywords: Poland, archaeological sites, loess, pollen analysis, TL dating, late Palaeolithic.

\section{INTRODUCTION}

Gathering information about natural environmental features of the Late Palaeolithic sites is a difficult research problem because of rare occurrence or even lack of organogenic deposits of the same age. We can overcome this problem, among other things, applying pollen analysis to mineral deposits that is rather rarely practised in Poland. Such analysis was our basis for the reconstruction of vegetation cover in two Palaeolithic sites of different ages, associated with covers of silt deposits (loess and loess-like deposits), situated in SE Poland. The samples of mineral deposits taken from these sites were also TL dated.

The research was carried out in a Late Magdalenian site near Wilczyce village in the eastern part of the Sandomierz Upland [1,2], and in a Final Palaeolithic site, with the Swidry Culture materials, on the periphery of Mucharz village in the eastern margin of the Small Beskid Mts, flysch Outer Carpathians [3]. Both sites are situated in the Vistula River basin (upland and mountain sections), in immediate vicinity of river valleys, i.e. the Opatówka and Skawa rivers,

*Address correspondence to this author at the Institute of Geological Sciences, National Academy of Sciences of Ukraine, O. Gonchar str. 55-b, 01054, Kyiv, Ukraine; Tel: +38044 23819 07; Fax: + 3804448693 34,

E-mail: makom@ukr.net respectively. The sites are situated about $190 \mathrm{~km}$ apart along a straight line SW-NE (Fig. 1).

\section{GEOMORPHOLOGIC SETTING}

\section{Vicinity of the Wilczyce Site}

The site is located in the eastern part of the Sandomierz Upland, on the Opatówka River. The Sandomierz Upland is a part of the Małopolska Upland, which is the western part of the Central Polish Uplands belt, separated by the Vistula River valley. The area of the Sandomierz Upland is covered by loess deposits (Fig. 1b), up to $30 \mathrm{~m}$ thick, accumulated during the Vistulian (Weischselian) glaciation. The upland landscape has typical features of loess relief [4]. Rather flat plateau is strongly dissected by the tributaries of the Opatówka and Koprzywianka rivers, which drain the upland area and flow into the Vistula River. The sub-parallel direction of the Opatówka River valley is conditioned by tectonic structures [5]. Its bottom consists of many basinshaped widenings and narrow (about $100 \mathrm{~m}$ wide) sections. The valley is bordered by loess hills with steep slopes, which are dissected by a dense network of small dry erosiondenudation valleys (Fig. 1d).

\section{Vicinity of the Mucharz Site}

The site is located in the eastern margin of the Small Beskid, which is characterized by the relief of medium, 

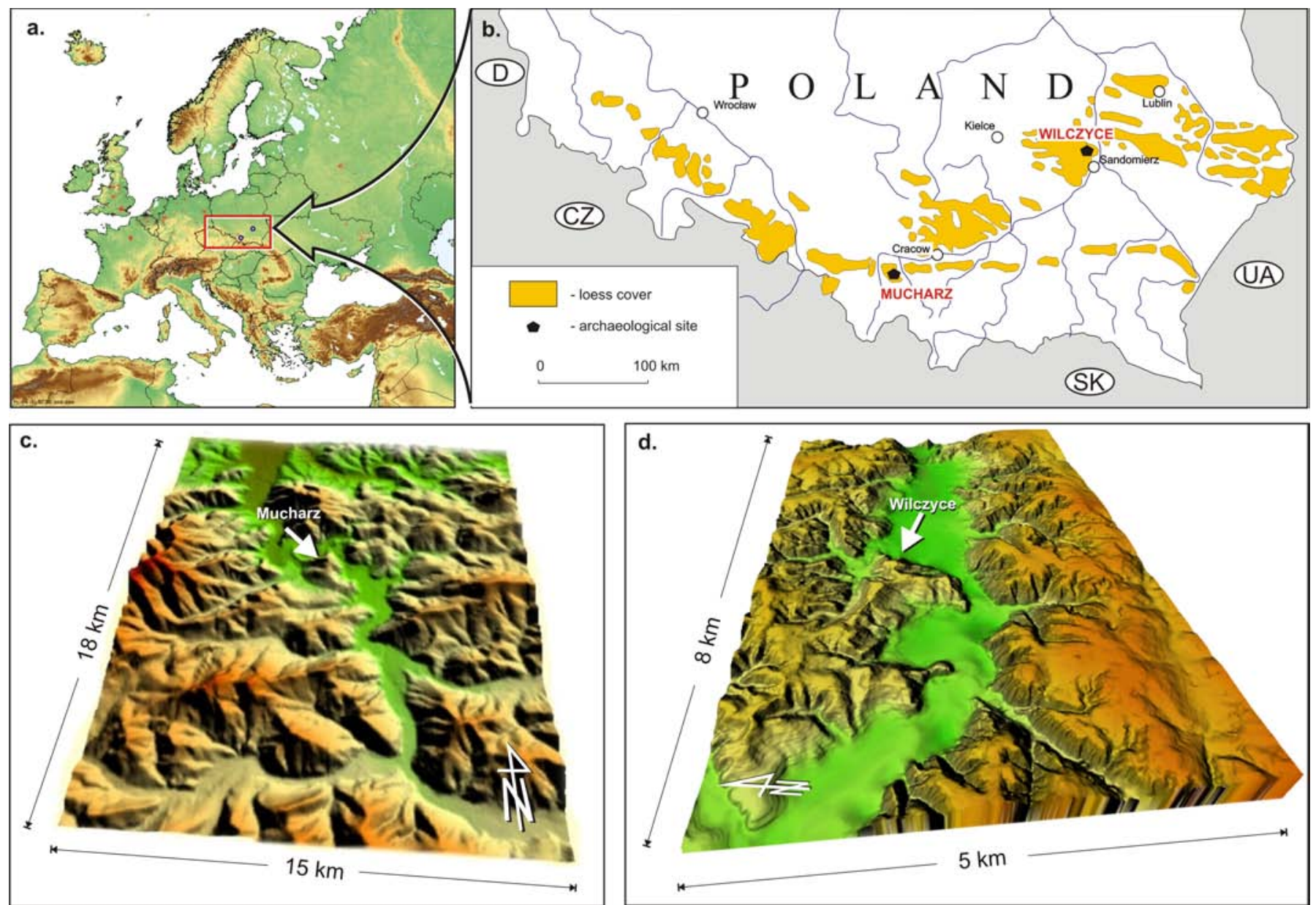

Fig. (1). Location of archaeological sites on the maps of: Europe (a), loess covers in Poland (b) and topographic models.

continuous and dissected mountains separated from the Middle Beskid by the Skawa River valley of gap nature (Fig. 1c). The Small Beskid is mostly composed of thick-bedded, weathering resistant Cretaceous sandstones. The Small Beskid mountain ranges, not exceeding $100 \mathrm{~m}$ a.s.l., are separated by narrow and deep valleys. Relative heights reach $600 \mathrm{~m}$. The Middle Beskid consists of many dismembered ranges composed of Magura sandstones interbedded with shales. Ridges are rounded and slopes are not very steep.

The Quaternary deposits are hardly found near the site. However, it should be mentioned that the South Polish ice sheet reached its maximum extent several kilometres of the site, as its lobe entered the Skawa River valley [6,7]. Its residual deposits (moraine) can be a source of flint erratic material. From among the younger Quaternary deposits, loamy and sandy deposits (generally defined as solifluction and deluvial ones) are more important. Specific loess-like loams of complex origin occur on river terraces. They resemble loess-like deposits of eolian and/or eolian-deluvial origin [8]. Sometimes such deposits are defined as the Carpathian variety of loess $[9,10]$.

\section{LOCATION AND DESCRIPTION OF SITES, AND ARCHAEOLOGICAL CONTEXT}

\section{Wilczyce Site}

The open-air site is situated on the top of isolated hill (198 m a.s.1.) forming the northern side of the Opatówka
River valley (Figs. 1d, 2). From the north it is bordered by a large dry erosion-denudation valley, and from the east - by a widening of the Opatówka River valley. It relative height is about $38 \mathrm{~m}$, and the maximum slope angle reaches $25^{\circ}$. A striking feature of the site surroundings is strong denudation of the Holocene soil cover connected with high relative relief and arable cultivation. Carbonate loess deposits are exposed on ground surface, and modern soils are weakly developed. Loess deluvia fill the bottoms of denudation valleys. Holocene alluvia form a thick (up to $6 \mathrm{~m}$ ) layer of in the bottom of the Opatówka River valley.

The site belongs to not numerous in Polish territory open camps [11]. The choice of place for camp was certainly not random because from the hill there is a vast view over the almost closed widening of the Opatówka River valley, and this fact was probably important for Magdalenian hunters [12]. The camp of hunters was located in a depression formed in place of a degraded ice wedge - a structure connected with polygonal cryogenic net evidencing the occurrence of permafrost. It was seasonal winter camp, used many times during a long period [2]. The archaeological materials found within the site include abundant faunal remains (horse, woolly rhinoceros, arctic fox, and hare, with some birds such as grouse, herring-gull and lesser blackbacked gull. A large number of bone and antler tools were also recovered. Several Lalinde/Gönnersdorf figurines, a 


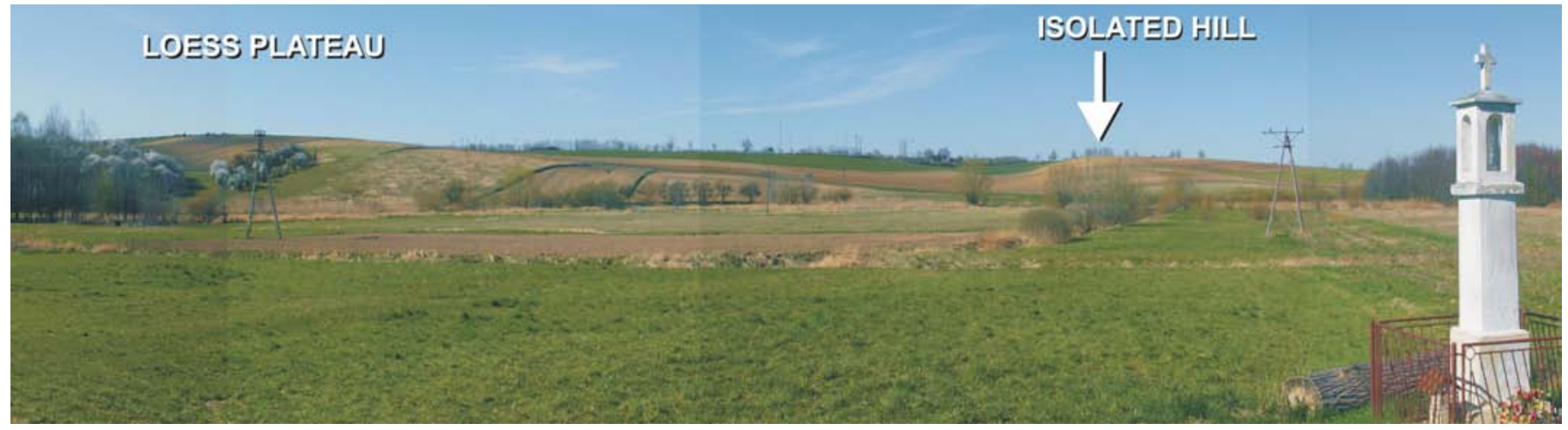

Fig. (2). View of the Wilczyce site from the bottom of the Opatówka River valley.

class Venus figurine, included a range of worked flint objects were recovered here [2].

\section{Mucharz Site}

The site is situated in the Skawa River gap through the Beskid Mts. The site lies on the undercut by erosion left bank of the river (Fig. 3), on the territory of the northern periphery of Mucharz village (a rather clearly isolated promontory of the Pleistocene terrace with loess-like cover, stretched at a height of about $305 \mathrm{~m}$ a.s.l. far inside a tight meander of the river). The terrace surface rises over $20 \mathrm{~m}$ above the river channel. This terrace can be related to the middle terrace of the Skawa River at Wadowice, which is covered with river sediments, slope (deluvial and solifluction) deposits separated by weathering (initial pedogenesis) and organic horizons, and several metres thick loess. This series, related to the Last Glacial, in total reaches $20 \mathrm{~m}$. The site is open-air and multicomponent, and the oldest settlement traces date back to 10, 000 years ago.

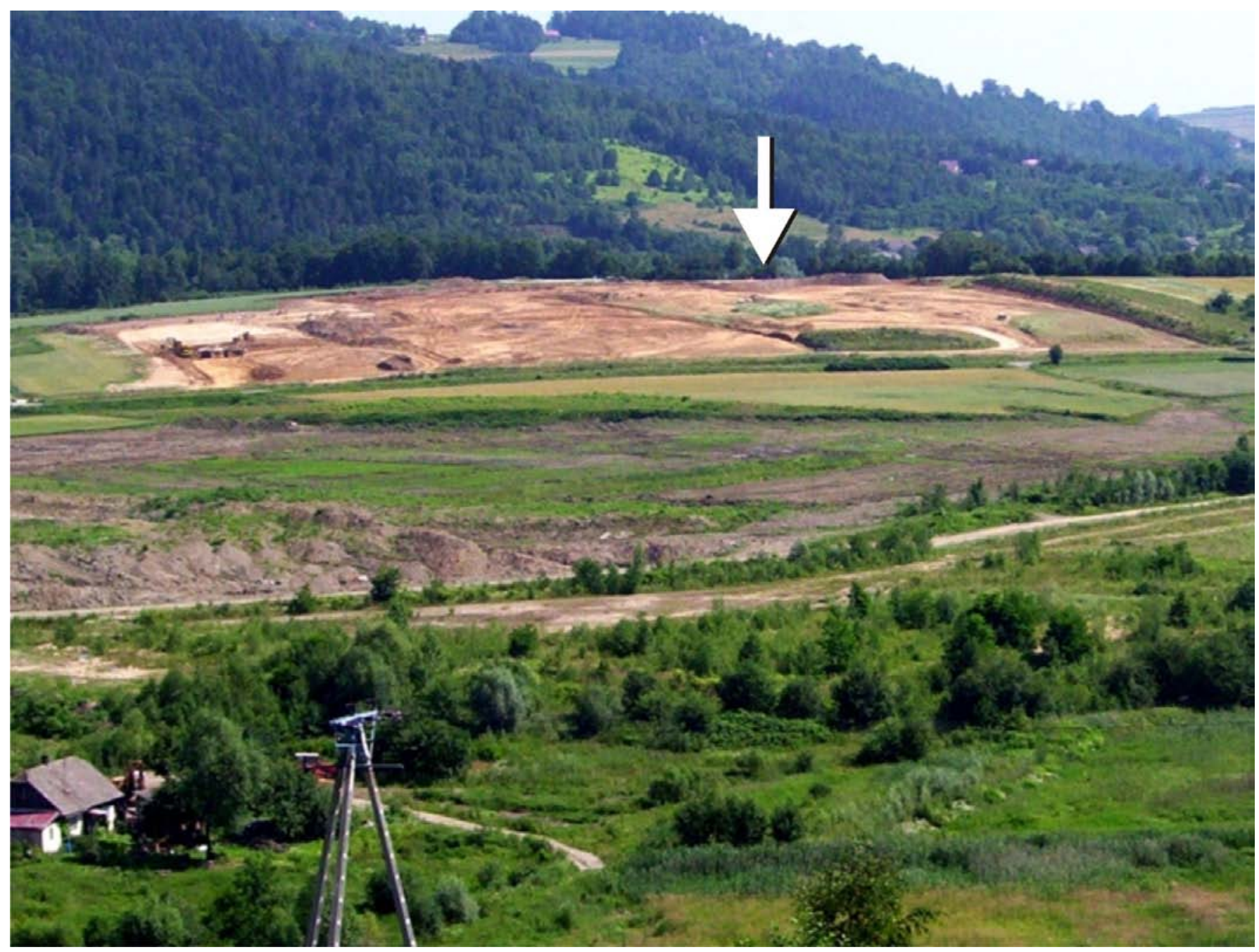

Fig. (3). View of the Mucharz site from the opposite slope of the Skawa River valley. 
Extremely rich finds of flint tools and arms date from this settlement phase, and are related to the so-called Świdry Culture. Population of this culture lived in small camps, rather temporary, that resulted from the necessity of moving after herds of reindeers. To date, the traces of this culture have been found mostly in the lowland area, and in the Carpathian Foothills the finds are rare. The Mucharz object is unique, and the only one in the Carpathians so far due to the found traces of "Świderian" shelter [3].

\section{METHODS AND FIELD INVESTIGATION}

Field investigations were carried out independently in both sites, in different time and scope. In the Wilczyce site the palaeoenvironmental studies started after the close of archaeological excavations. Such a situation demanded special methods of fieldwork. In the site itself, a small fragment of the excavations was open again, and deposit samples for pollen analysis were taken (marked by W). Three sampling points were situated close each other: W1 by the border of the ice wedge cast but outside it, W2 inside the wedge, W3 - by the border but inside the wedge. The sample W7 was taken from surrounding deposits (primary loess) at a distance of $1,5 \mathrm{~m}$ from the wedge (Fig. 4). All these samples were TL dated. In order to reconstruct the deposition environment of underlying deposits, i.e. to characterize losses and deforming them cryogenic structures, a pit (over $2 \mathrm{~m}$ deep, $50 \mathrm{~m}$ long, Fig. 5a, b) was dug in the nearest vicinity of the site. The surface of discontinuity, clearly visible in the pit wall and related to a ground palaeosurface (Fig. 6), evidences a short (interphase-type?) interruption in loess deposition. Two samples (W4 and W5) for pollen analysis, four samples for TL dating, and four samples for micromorphological analyses were taken from the pit. The sample W4 was taken above the discontinuity line and the sample W5 - below.

During excavations in Mucharz site the investigations were conducted in two objects of the Swidry Culture. Four samples (M1-M4) for pollen analysis and four samples for TL dating were taken from sediment filling and covering a basin-shaped depression, which was recognized as the aboveground dwelling structure in the object 39 (Fig. 7). Additionally, three samples for TL dating were taken from the object 717 [3]. Thermoluminescence dating was made using the total-bleach method, which has the least limitations resulting from the physical features of the dated material [13].

\section{METHOD OF POLLEN ANALYSIS}

The palynomorphs from each sample of $100 \mathrm{~g}$ dry weight were extracted using modified methods for processing of mineral samples. Hot hydrochloric acid (10\%) was used to remove carbonate minerals. $10 \% \quad \mathrm{Na}_{4} \mathrm{P}_{2} \mathrm{O}_{7}$ was used to disaggregate the sediment, then sieving with nylon screens to remove the sand fraction. $18 \% \mathrm{H}_{3} \mathrm{PO}_{4}$ was used to remove possible $\mathrm{Fe}_{2} \mathrm{O}_{3}$ sporomorph's cover. Palynomorphs were separated from mineral material by means of heavy liquid flotation method (specific weight $=2.2 \mathrm{~g} / \mathrm{cm}^{3}$ and $2.0 \mathrm{~g} / \mathrm{cm}^{3}$ ). Then samples were put in $52 \%$ hydrofluoric acid for $24 \mathrm{~h}$ to remove silicates. Acetolysis treatment was not used because it makes more difficult to distinguish the redeposited palynomorphs from the contemporary ones. The processed pollen residues are treated with glycerine + water solution and

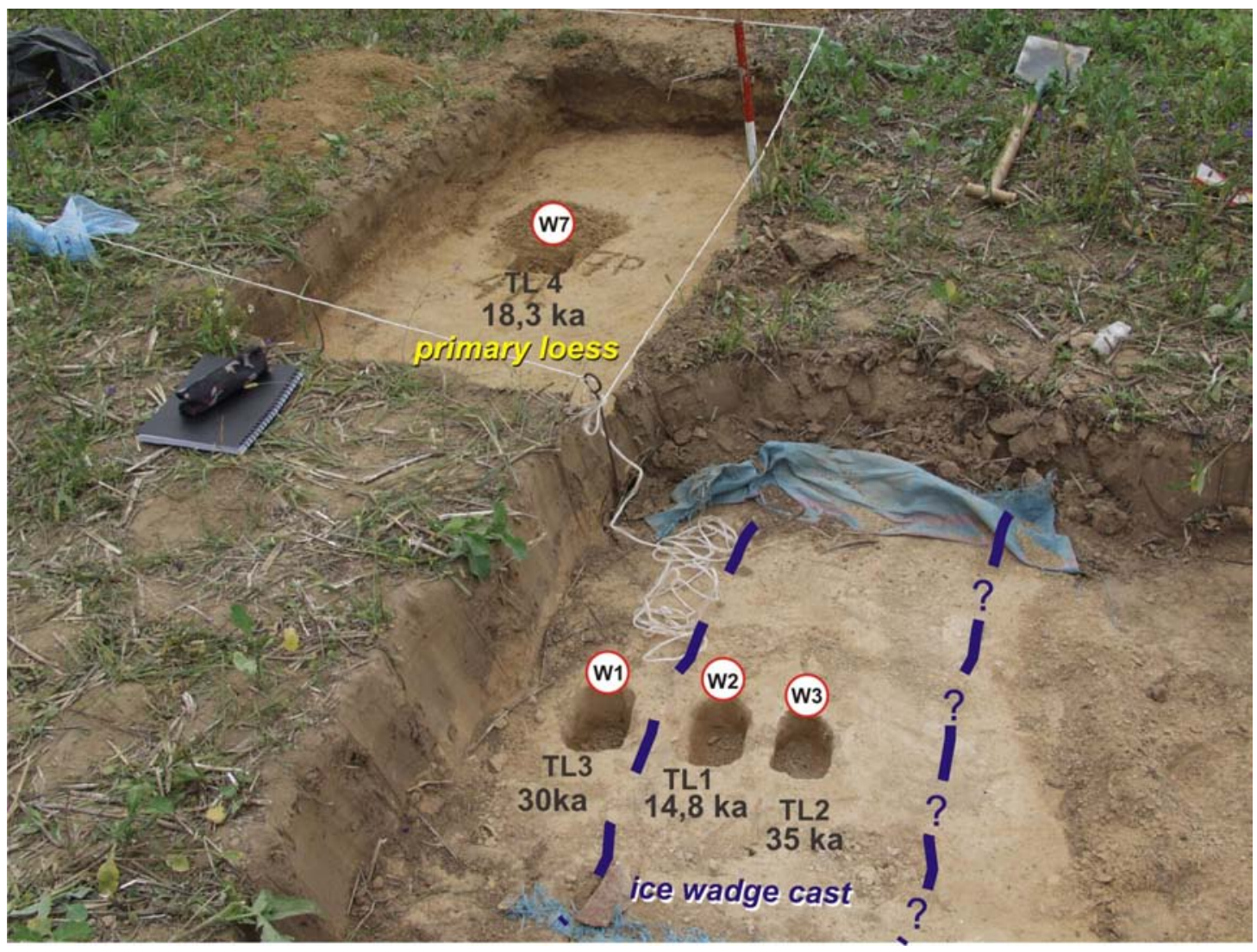

Fig. (4). Wilczyce site - position of TL and palynological samples. 
a.

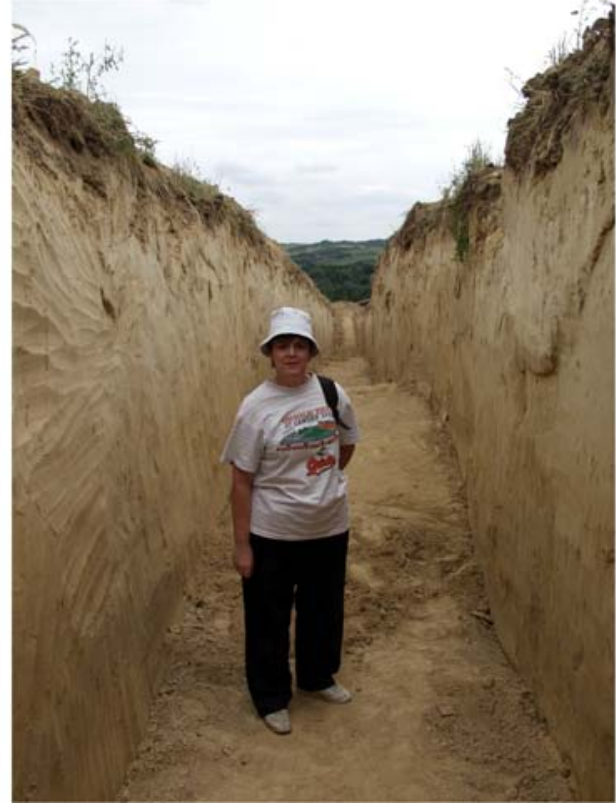

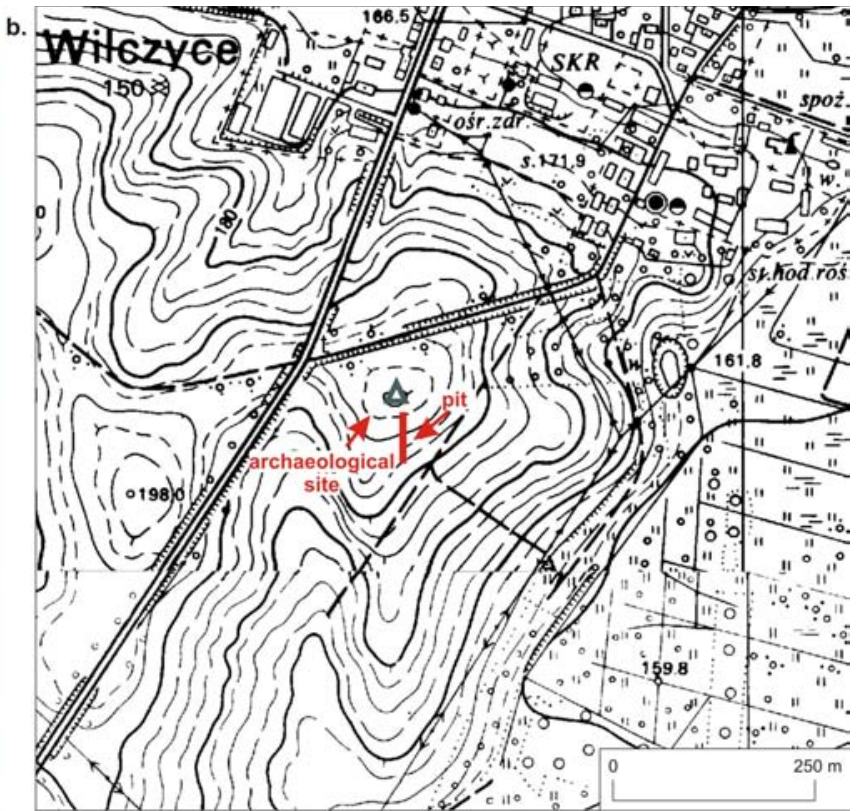

Fig. (5). Pit in loess cover (a; M. Komar as the scale) and its situation relative to the archeological site (b).

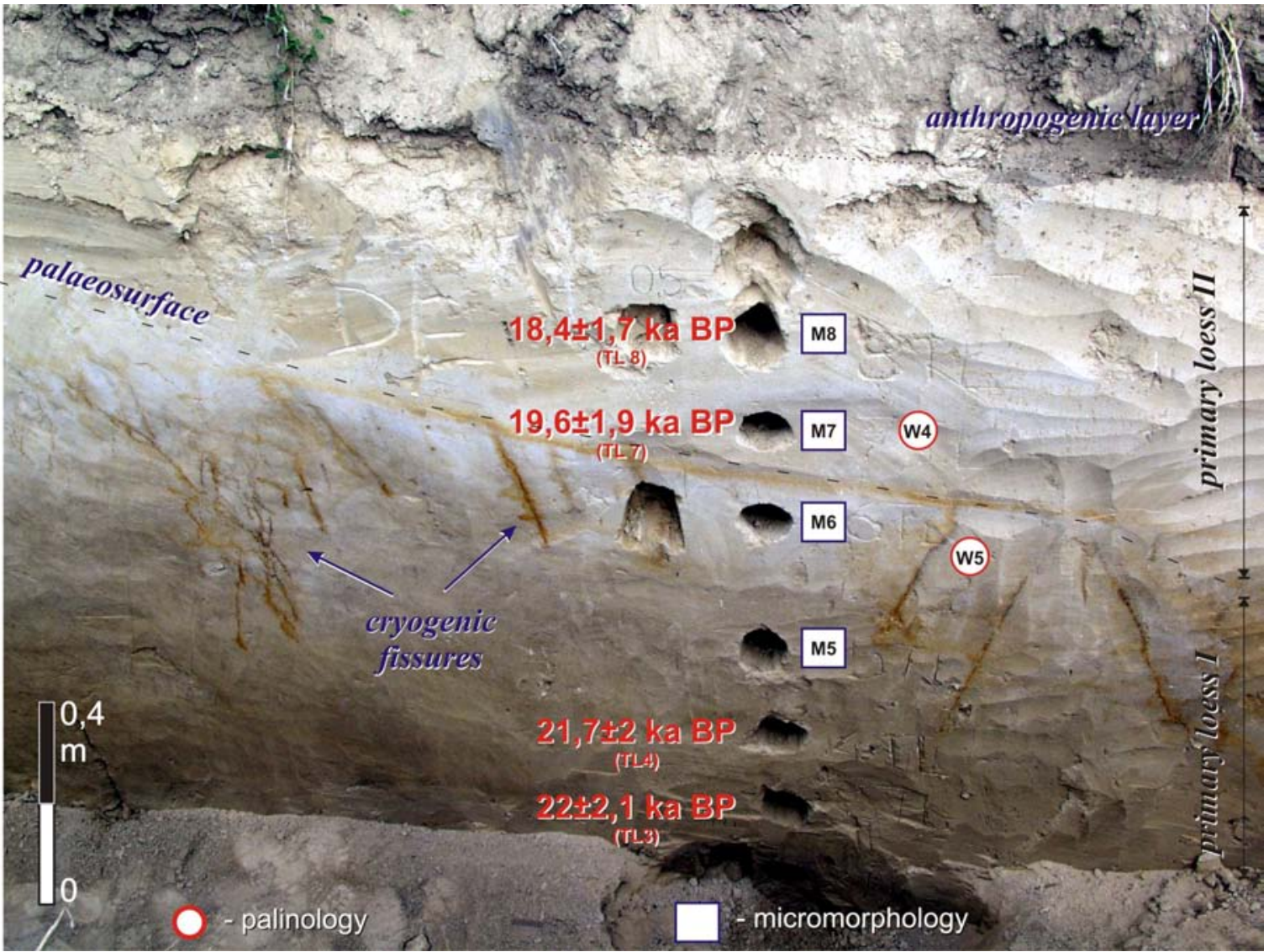

Fig. (6). Wilczyce site - the age and position of samples in the pit.

routinely counted at a magnification of 600 , using a Zeiss microscope. Slides were made from the whole processed material, and pollen grains were counted on the whole slide surface. The results were subjected to statistical analysis and presented in the form of pollen histograms and cyclograms with the use of EXEL programme. The frequency of sporomorphs was different in the particular samples. The percentages of particular taxa were calculated in relation to the total sum $(\mathrm{AP}+\mathrm{NAP}+\mathrm{P})$, including pollen grains of trees and shrubs (AP), of dwarf shrubs and terrestrial herbs (NAP) and spores (P). Pollen of aquatic plants, varia and redeposited palynomorphs were excluded from the total sum but their percentages were also calculated in relation to this sum. 


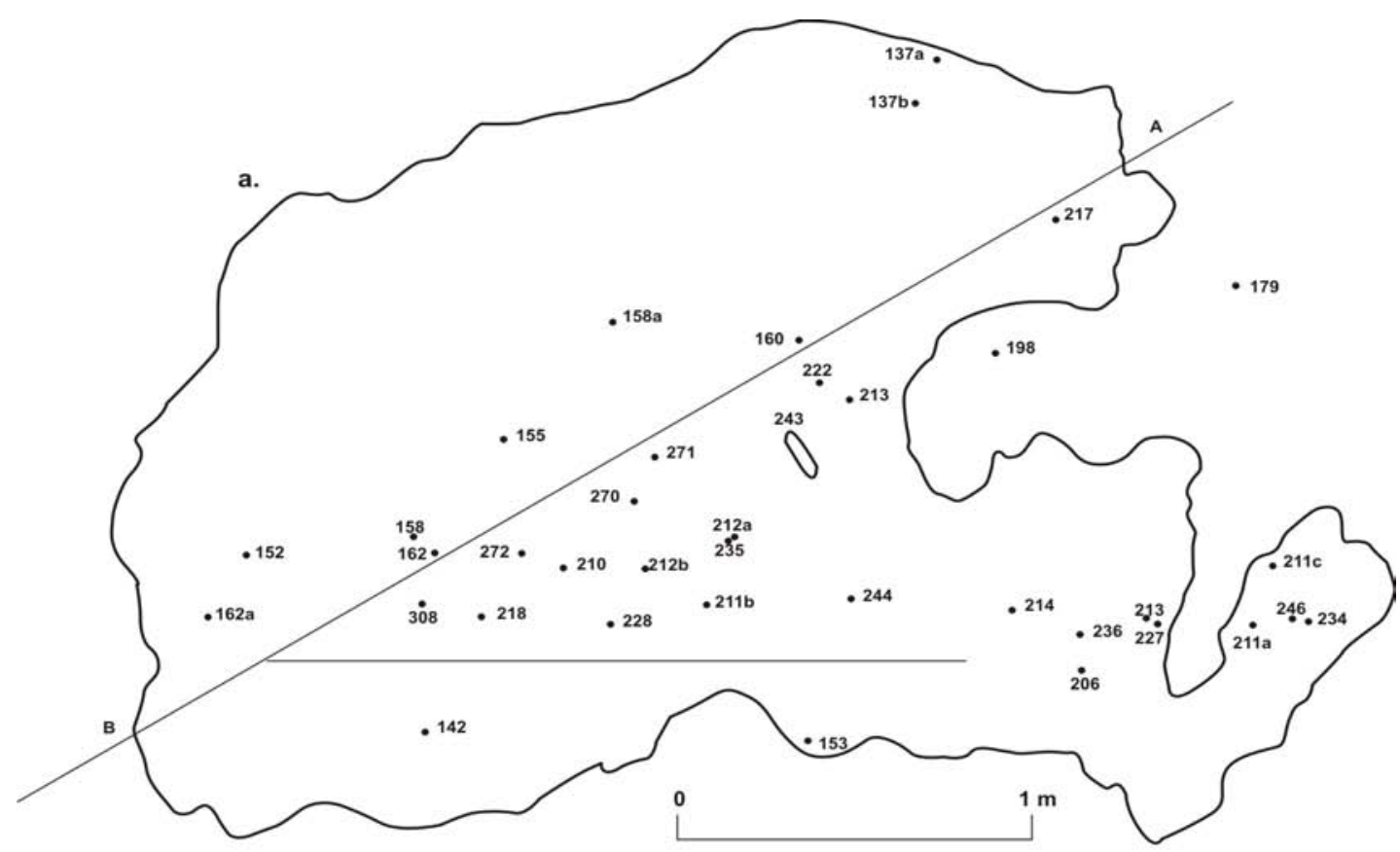

b.

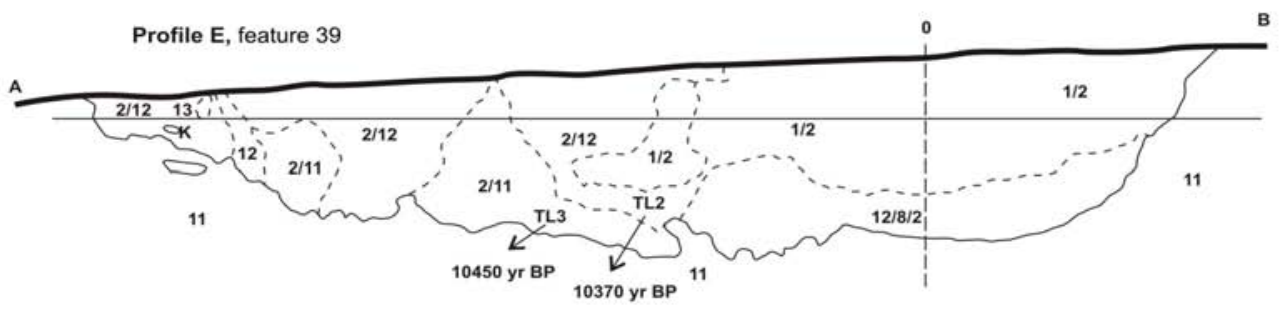

c.

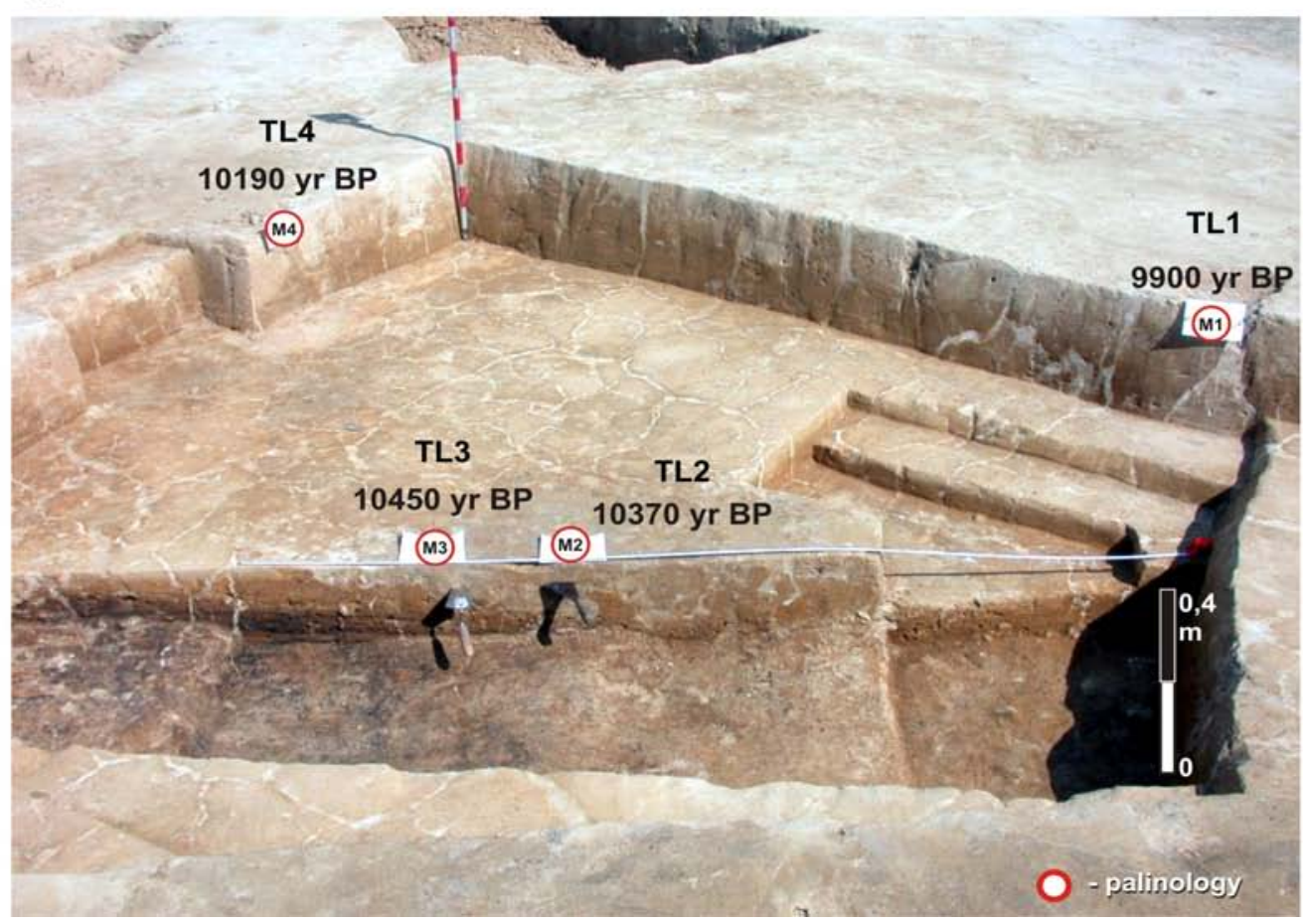

Fig. (7). Mucharz site - planigraphy (a), cross-section (b) (according to Valde-Nowak, Lanczont, 2008) and pit (no. 39) with marked position of TL and pollen samples (c). 


\section{RESULTS OF INVESTIGATIONS}

\section{Palynological Analysis of Mineral Deposits}

Frequency of palynomorphs in particular samples was different, sometimes rather high. Palynomorphs were rather well preserved; corroded or damaged grains were rare. The total sum for percentage calculations ranged from 169 to 217 grains in the Wilczyce site, and from 144 to 628 in the Mucharz site.

\section{Wilczyce Site}

The results of pollen analysis are described according to similarity of taxonomic composition of spectra.
Spectra of the samples W1 and W2 indicate the spread of communities composed of Chenopodiaceae, grasses, and sedges with sea buckthorn (Hippophaë rhamnoides). Pollen of Selaginella selaginoides and spores of Bryales can confirm the occurrence tundra vegetation patches. Pollen of Pinus sylvestris and P. cembra can be probably related to the existence of small patches of trees (in favourable habitat conditions) though its long transport was possible (Fig. 8).

The spectra of the samples W3 and W7, slightly different from the rest, are characterized by the occurrence of pine and spruce pollen that was not found in the samples W1, W2, W4, and W5. Similarly as the spectra W1 and W2, they contain rather high pollen values of Artemisia,

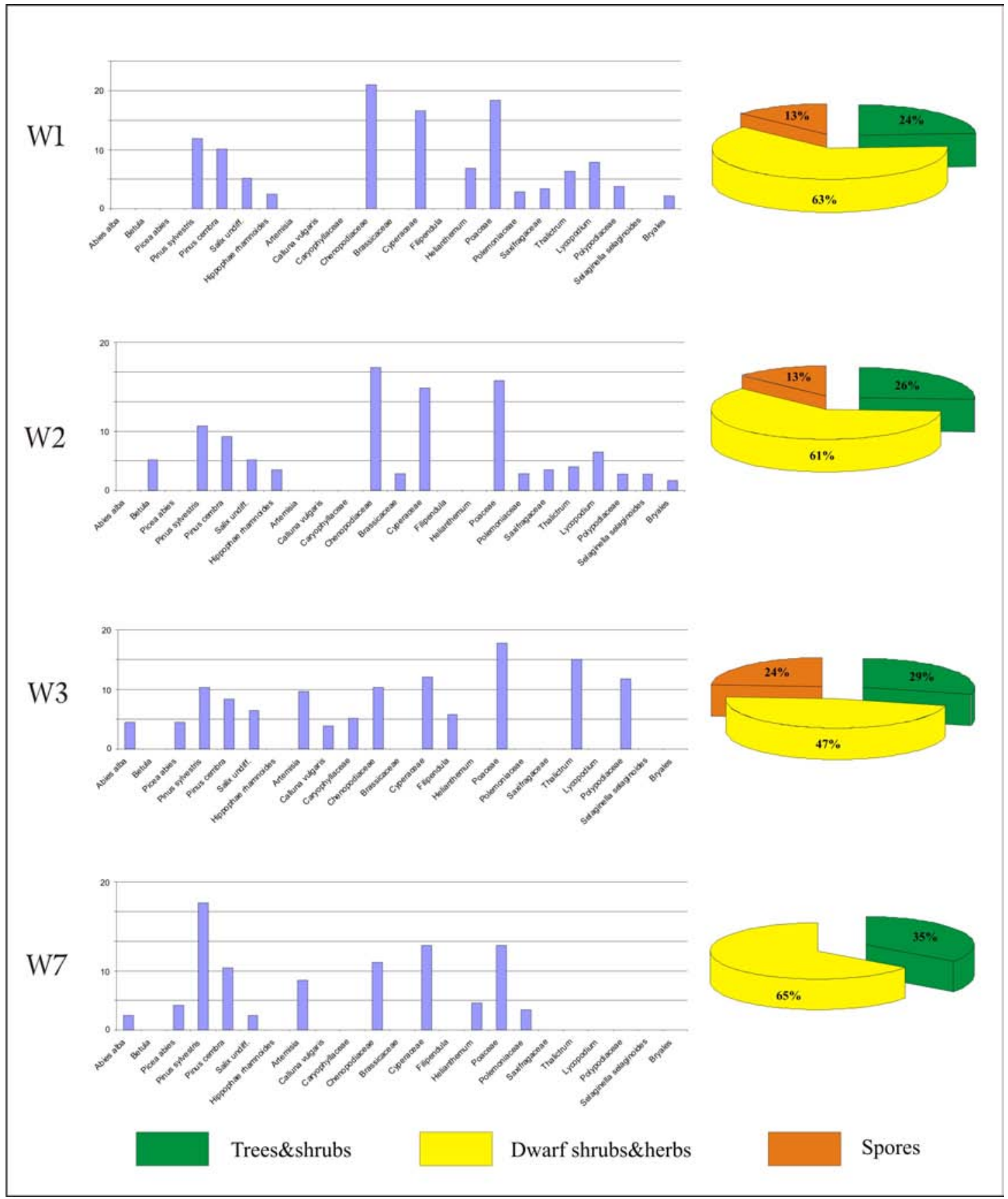

Fig. (8). Histograms and cyclograms showing the pollen percentages in the examined samples in Wilczyce site. The sample location see in Fig. (4). 

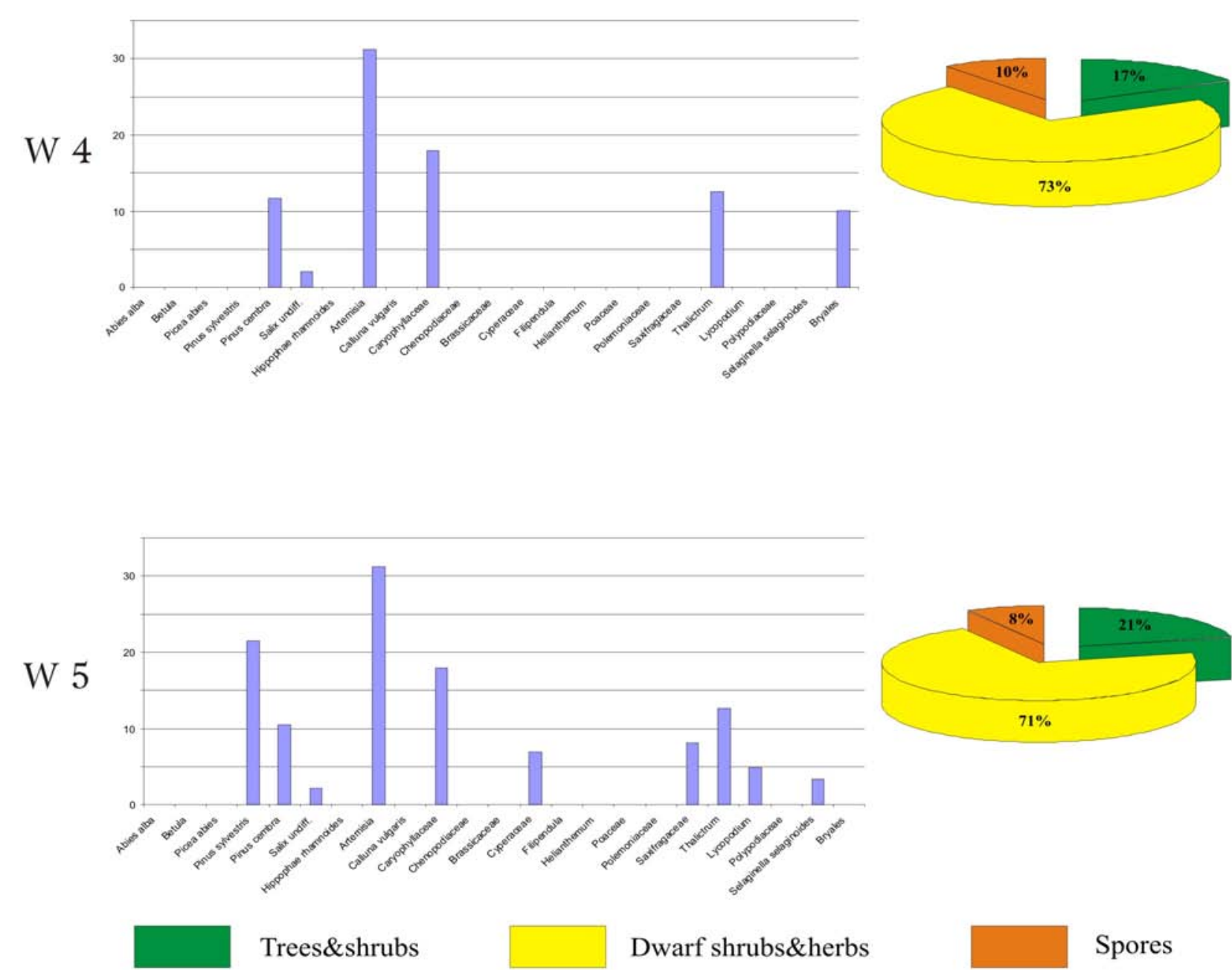

Dwarf shrubs\&herbs

Spores

Fig. (9). Histograms and cyclograms showing the pollen percentages in the examined samples from the pit in Wilczyce site. The sample location see Fig. (6).

Chenopodiaceae, Cyperaceae and Poaceae but Hippophä rhamnoides and indicators of wet tundra are absent (Fig. 8).

Spectra of the samples W4 and W5 are characterized by rather low AP values, i.e. $17 \%$ and $21 \%$, respectively, and very low taxonomic diversity of the recorded pollen flora. Most of the AP grains belong to Pinus genus (Pinus cembra and $P$. sylvestris). Pollen of Salix is considerably less numerous. NAP pollen makes about $70 \%$ of total sum, and is dominated by pollen of Artemisia, Thalictrum, and Caryophyllaceae. These spectra can indicate the period of non-forest communities predomination, i.e. a mosaic of dry steppe with tundra patches (Selaginella selaginoides, Saxifragaceae, Bryales), and also, similarly as in the spectra W3 and W7, the probable occurrence of tree patches (Pinus sylvestris, $P$. cembra). Their different features, compared with the spectra W1 and W2, are the predominance of herb communities with Artemisia (Fig. 9).

\section{Mucharz Site}

The samples M2 and M3, characterized by the absence of Picea pollen and higher amount of redeposited pollen, can represent a somewhat older period of sediment deposition
(Fig. 10). The samples M1 and M4 were taken from the sediments that were probably deposited later. This conclusion is confirmed by the results of TL dating.

Pollen spectra of samples taken from the fill and its direct cover are characterized by high values of coniferous trees (Pinus sylvestris, P. cembra and Picea), and the occurrence of Salix, Betula sect. Alba, Alnus incana among deciduous trees and shrubs (Fig. 10). The percentages of spores (Lycopodium clavatum, L. annotinum, Huperzia selago, Diphazium tristachyum, D. complanatum, Selaginella, Botrychium boreale, Riccia, Polypodiaceae and Bryales) are rather high. From among herbs, the highest values are reached by pollen of Poaceae and Caryophyllaceae. Pollen grains of Cichoriaceae, Asteraceae, Cyperaceae, Brassicaceae, Apiaceae, Ranunculaceae, Chenopodiaceae and Polygonum minus are less numerous.

\section{TL Dating}

\section{Wilczyce Site}

Loesses underlying the site are little diversified and represent primary, carbonate loess type. Two levels of wedge 
Table 1. The Results of TL Dating from the Archaeological Site and Geologic Pit in Wilczyce

\begin{tabular}{|c|c|c|c|c|c|c|}
\hline Lab. No. Lub- & Sample No. & Description & Depth & $\begin{array}{c}\text { Dose Rate DR } \\
\text { (Gy/ka) }\end{array}$ & $\begin{array}{c}\text { Equivalent Dose } \\
\text { ED (Gy) }\end{array}$ & TL Age (ka BP) \\
\hline \hline 4475 & TL1/o & Wedge border & $0.30 \mathrm{~m}$ & $3.14 \pm 0.16$ & $47 \pm 4$ & $14.8 \pm 1.4$ \\
\hline 4476 & TL2/o & Wedge centre & $0.30 \mathrm{~m}$ & $2.63 \pm 0.13$ & $92 \pm 7$ & $35 \pm 3.3$ \\
\hline 4477 & TL3/o & Outside the wedge & $0.30 \mathrm{~m}$ & $2.99 \pm 0.15$ & $39 \pm 7$ & $58 \pm 5$ \\
\hline 4478 & TL4/o & Outside the wedge & $0.30 \mathrm{~m}$ & $3.17 \pm 0.16$ & $38 \pm 2.9$ \\
\hline 4486 & TL8 & Pit & $0.65 \mathrm{~m}$ & $3.16 \pm 0.16$ & $5.3 \pm 1.7$ \\
\hline 4485 & TL7 & Pit & $0.85 \mathrm{~m}$ & $3.14 \pm 0.16$ & $62 \pm 5$ & $18.4 \pm 1.7$ \\
\hline 4481 & TL3 & Pit & $2.00 \mathrm{~m}$ & $3.28 \pm 0.16$ & $71 \pm 6$ & $21.7 \pm 2$ \\
\hline 4480 & TL2 & Pit & $2.25 \mathrm{~m}$ & $3.01 \pm 0.15$ & $67 \pm 5$ & $22 \pm 2.1$ \\
\hline
\end{tabular}

structures are visible in vertical section. The older one is probably composed of large polygons. The younger structures are preserved only in their bottom part; the upper part was removed by Holocene erosion. The traces of the Magdalenian settlement are probably connected with the younger generation of wedge casts. TL dating indicates that the loess age is between 22 and $18 \mathrm{ka} \mathrm{BP}$ (Table 1, Fig. 6).

The remains of the camp were dated by archaeologists at $15 \mathrm{ka}$ BP $[1,2,12]$. This age well corresponds with the TL date (14.8 $\pm 1.4 \mathrm{ka} \mathrm{BP})$ obtained for a deposit sample taken inside the ice wedge but near its border. Two other samples (from the wedge centre $-35 \pm 3.3 \mathrm{ka} \mathrm{BP}$, and from the sediment outside the wedge - $30 \pm 2.9 \mathrm{ka} \mathrm{BP}$ ) were considerably older that can be explained by a distinct hiatus between the archaeological site and surrounding loess. It is possible that in very dynamic permafrost active layer, in which ice wedges were formed, plastic loess was mixed near these structures, and older material was extruded upward. These phenomena could have been responsible both for the overestimation of some TL dating results (TL2/o, TL3/o) and problems with correlation of pollen spectra (Table 1, Fig. 4).

\section{Mucharz Site}

Loess-like silty and silty-sandy deposits occurring in the site environs have a high content of the $0.05-0.02 \mathrm{~mm}$ fraction that is preferred for TL dating in the Lublin laboratory [13]. Only the sample No2/717 represents the alluvial mixture of sandy, gravely and loamy material, so its deposition time cannot be unambiguously determined (Table 2).

The TL ages obtained for both objects (39 and 717) are within the narrow range (11200-9900 years BP), and form a logical pattern, both vertically and horizontally. They well correspond with geologic-stratigraphic situation of the examined objects, which can be described as irregular concave forms and their fill. TL dates, which came from the fill of two objects $(10370 \pm 913,10450 \pm 836,10630 \pm 1170$, $11020 \pm 1200$ years BP), indicate the Younger Dryas. Two other TL dates came from sediment covering the object ( $9900 \pm 911$ years BP and $10190 \pm 876$ years BP) [3]

\section{PALAENVIRONMENT CONTEXT}

\section{Loess Uplands}

The examined loess deposits were accumulated in the Sandomierz Upland during the upper Plenivistulian, i.e. about 18-22 ka BP. In the light of micromorphological analyses, they contain an admixture of older, evidently redeposited loess material as indicated by pedorelictic microfeatures: illuvial papules (fragmented clay coatings formed in situ in Bt soil horizon) and also $\mathrm{Fe}$ and $\mathrm{Mn}-\mathrm{Fe}$ nodules (reworked older diffuse nodules) (Table $\mathbf{3}$ ) according to Mroczek [14] description. The loess was deposited in the environment of dry steppe with tundra patches. The landscape was open, with a large contribution of Artemisia communities. Patches of coniferous trees occurred probably in ecological niches on valley sides [15] though long transport of their pollen was also possible. Climate of the older stage of the described period could have been slightly wetter as indicated by the occurrence of Selaginella selaginoides, Saxifragaceae, Bryales, and Salix. The younger stage was characterized by ArtemisiaChenopodiaceae steppe communities with sedges and grasses (tundra indicators - Selaginella selaginoides, Bryales - were absent).

Pollen spectra of samples taken from the archaeological site (fill) and its direct surroundings confirm quite cold climate in the final stage of loess accumulation. They represent open landscape with Chenopodiaceae, grasses, sedges, and also sea buckthorn (Hippophaë rhamnoides) but without Artemisia. These steppe communities formed a mosaic with vegetation of wet tundra habitats with Selaginella selaginoides, Bryales, and Saxifragaceae. Patches of tree vegetation, i.e. Pinus sylvestris, P. cembra and Abies alba, probably also occurred. It is safe to assume that a mosaic of habitats occurred near the site, with patches of park-type forest-tundra with pine. The occurrence of fir pollen in the Vistulian biogenic deposits in the Polish area is usually related to redeposition [15-17]. However, taking into account the good state of preservation of fir pollen grains, we suppose that single trees could have survived in ecological niches that probably occurred on southern slopes 


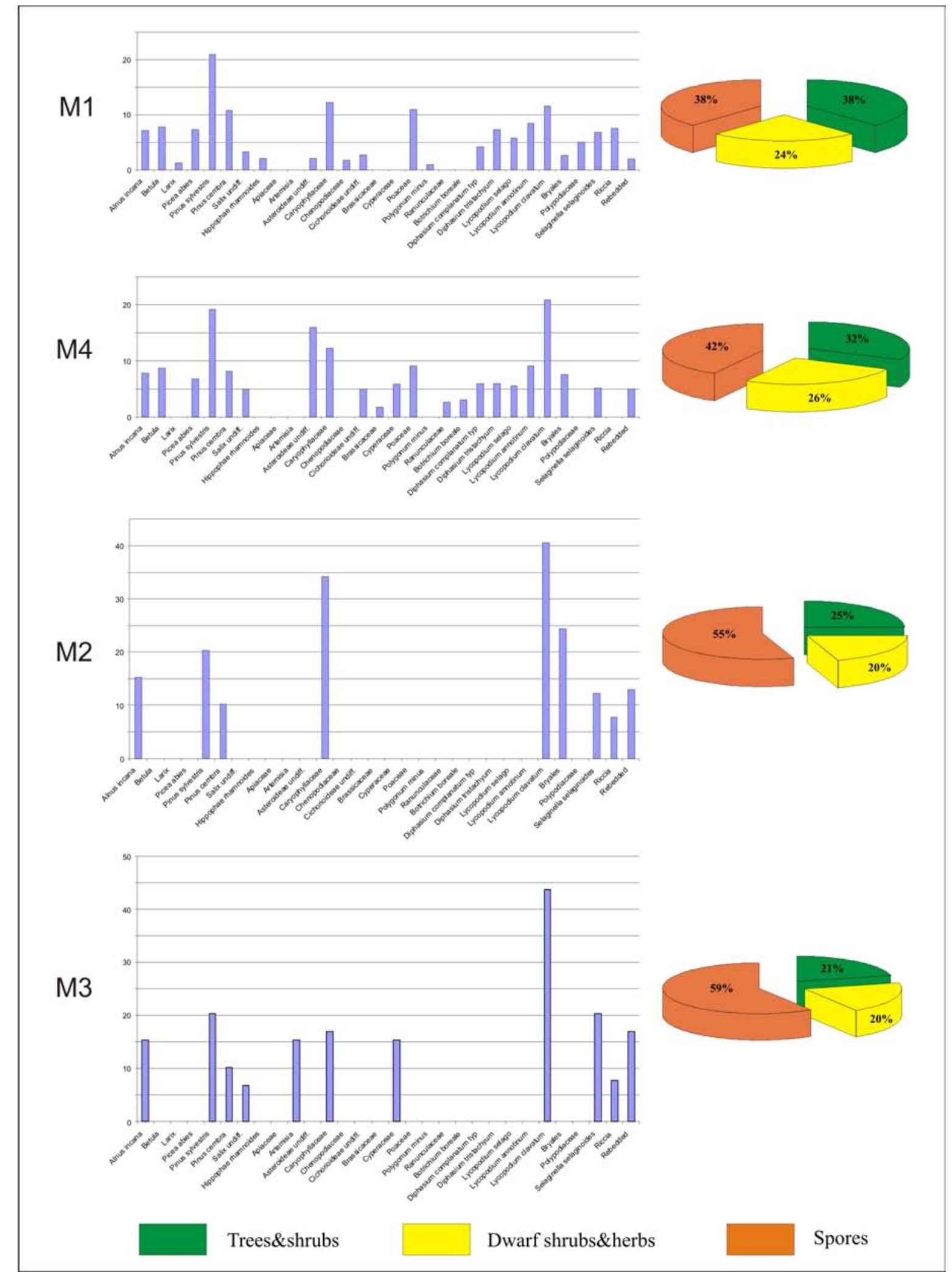

Fig. (10). Histograms and cyclograms showing the pollen percentages in the examined samples directly in Mucharz site. The sample location see Fig. (7).

of the deep latitudinal Opatówka River valley, similarly as in the Kraków environs [18]. This problem needs further studies.

\section{Carpathian Foothills}

The high pollen values of coniferous trees and rather high spore frequencies are typical features of the examined spectra. These spectra are the evidence of quite cold climate 
Table 2. The Results of TL Dating from the Archaeological Site in Mucharz

\begin{tabular}{|c|c|c|c|c|}
\hline Lab. No. Lub- & Sample No. & Dose Rate DR (Gy/ka) & Equivalent Dose ED (Gy) & TL Age(ka BP) \\
\hline \multicolumn{5}{|l|}{ Object 39} \\
\hline 4361 & TL2 & $3.09 \pm 0.15$ & $32 \pm 2.5$ & $10370 \pm 913$ \\
\hline 4362 & TL3 & $3.25 \pm 0.17$ & $34 \pm 2.5$ & $10450 \pm 836$ \\
\hline \multicolumn{5}{|l|}{ Object 717} \\
\hline 4378 & TL1 & $3.55 \pm 0.30$ & $37.7 \pm 3$ & $10630 \pm 1170$ \\
\hline 4379 & TL2 & $3.07 \pm 0.27$ & \multicolumn{2}{|c|}{ without result } \\
\hline 4380 & TL3 & $3.59 \pm 0.29$ & $39.6 \pm 3$ & $11020 \pm 1200$ \\
\hline
\end{tabular}

Table 3. Selected Micromorphological Features of Loess Sediments from Pit in the Wilczyce Archaeological Site. The Frequency of Features is Recorded in Number of Crosses: One (+) Mark Single, and Four (++++) Common Presence; the Diameters are in Microns

\begin{tabular}{|c|c|c|c|c|}
\hline \multirow{2}{*}{ Sample No. } & \multirow{2}{*}{ Microstructure } & \multicolumn{2}{|c|}{ Pedorelicts } \\
\cline { 3 - 5 } & & Papules & Mn-Fe Nodules with Sharp Boundaries & Fe Nodules with Sharp Boundaries \\
\hline \hline M5 & massive, channel & $+(500)$ & $++(500)$ & $++(400)$ \\
\hline M6 & masieve, channel & $+(500)$ & $++(300)$ & $+(300)$ \\
\hline M7 & platy & $+++(600)$ & $++(700)$ & $++(800)$ \\
\hline M8 & platy & $+++(800)$ & $++(800)$ & $++(600)$ \\
\hline
\end{tabular}

period. The comparison with the published Late GlacialHolocene pollen diagrams from the areas situated to the north $[19,20]$ and to the south $[21,22]$ of the Mucharz site indicates that the composition of analysed spectra resemble rather those from the Carpathian sites due to high pollen values of Pinus cembra. In the Carpathian diagram the high percentages of Pinus cembra pollen (Pinus-P. cembraArtemisia pollen zones) are related to the Younger Dryas [22]. Therefore, it can be assumed that the examined deposits were also deposited in the Younger Dryas period. In the Carpathian diagrams the occurrence of spruce pollen is recorded since the Late Glacial but its frequencies increase in the Early Holocene, simultaneously with the decrease of Pinus cembra pollen values. Assuming that pollen found in the examined deposits represents the vegetation surrounding the studied archaeological site (though long transport of pollen is possible) we can conclude that open coniferous forests, with such plants as Lycopodium, Diphazium, Huperzia and others, occurred near the site. The presence of Selaginella spores confirms the occurrence of tundra communities on wet habitats, while dry places were covered by xerophytes with Artemisia, Caryophyllaceae, Cichoridaceae, Asteraceaceae, and Hippophaë rhamnoides. The occurrence of Alnus incana pollen is puzzling. Grey alder forms modern riverine forests growing on river alluvia accumulated mostly in low mountains areas and mountain basins [23]. In the quoted pollen diagrams (Obidowicz 1996) only sporadic occurrence of Alnus viridis pollen is recorded, very low curve of Alnus undiff. appears only in the Late
Glacial, and the development of alder communities is related to the Boreal period.

After settlement retreat the vegetation succession changed, and coniferous forests were developing, with an admixture of birch and then hazel (macroremnants) and alder.

\section{CONCLUSIONS}

Extensive palaeoenvironmental investigations of two different sites of different age at Wilczyce and Mucharz evidence a similar character of seasonal camp locations in quite cold climate at the close of the Plenivistulian and Late Vistulian. These camps were made in park-tundra landscapes with specific relief. The both sites are situated in gap sections of river valleys. Due to such location the sites have several advantages: the occurrence of excellent observation and signal points, and natural traps for migrating herds of game, rich pasturage in bottoms of river valleys and on adjacent slopes, proximity of water.

Interpretation of pollen analysis of loess deposits is very difficult, and sometimes arguable due to the way of their accumulation. However, the results of pollen analysis turned out to be very promising because the spectra obtained from different places reveal some similarities, and allow us to characterize vegetation cover. In the Wilczyce site case, the results of pollen analysis well correspond with the results of palaeozoological studies (Fiedorczuk et al. 2007). The remains of horse and woolly rhinoceros together with carnivores point to sufficient food for the local sustenance of 
groups of large herbivores [24]. These environmental features, together with specific relief, were the cause of repeated stays of hunters' groups in the same place in winter seasons [12].

\section{ACKNOWLEDGEMENTS}

This work has been partially financed in 2007 by Vicechancellor for Science of the Maria Curie-Skłodowska University (Poland) as a part of the project entitled "Palaeographical context of the Magdalenian site at Wilczyce village on the Opatówka River (Sandomierz Upland)", the head - Maria Łanczont.

\section{REFERENCES}

[1] Fiedorczuk J, Schild R. Wilczyce - a new late Magdalenian site in Poland. In: Valentin B, Eriksen B, Bratlund B, Eds. Recent studies in the final palaeolithic of the European plain. Åarhus: Jutland Archaeological Society 2002; pp. 91-100.

[2] Fiedorczuk J, Bratlund B, Kolstrup E, Schild R. Late Magdalenian feminine flint plaquettes from Poland. Antiquity 2007; 81: 97-105.

[3] Valde-Nowak P, Łanczont M. Late Palaeolithic dwellings from Skawa Gorge in the Beskidy Mts. (Polish Carpathians). In: Sulgostowska Z, Tomaszewski AJ, Eds. Man-MillenniaEnvironment, Studia in honour of Professor Romuald Schild. Warszawa IAiE PAN 2008; pp. 215-23.

[4] Czarnecki R. Wyżyna Sandomierska, część wschodnia, I, Komponenty krajobrazu geograficznego (Sandomierz Upland, eastern part, I, Components of geographical landscape). Warszawa 1996.

[5] Kosmowska-Suffczyńska D. Rozwój rzeźby w trzeciorzędzie okolic Ostrowca Świętokrzyskiego i Ćmielowa (Relief development in Tertiary near Ostrowiec Świętokrzyski and Ćmielów). Prace Geogr. IGPAN 1966; p. 52.

[6] Dudziak J. Głazy narzutowe na granicy zlodowacenia w Karpatach Zachodnich (Erratics on glaciation boundary in the Western Carpathians). Prace Geologiczne Komitetu Nauk Geologicznych PAN. Warszawa: Wydawnictwa Geologiczne 1961; p. 5.

[7] Marks L, Ber A, Gogołek W, Piotrowska K. Geological Map of Poland 1:500 000. Warszawa, Państwowy Instytut Geologiczny, 2006.

[8] Alexandrowicz SW, Butrym J, Krysowska-Iwaszkiewicz M, Zuchiewicz W. Profil utworów lessopodobnych w Siennej koło Nowego Sacza (Less-like deposits section at Sienna near Nowy Sacz). In: Maruszczak H, Ed. Podstawowe profile lessów w Polsce (Main sections of loesses in Poland). Lublin 1991; pp. 156-64.

[9] Gerlach T, Krysowska-Iwaszkiewicz M, Szczepanek K, Alexandrowicz SW. Karpacka odmiana lessów w Humniskach koło Brzozowa w polskich Karpatach fliszowych (The Carpathian variety of loesses at Humniska near Brzozów in the Polish flysch Carpatians). Geologia 1991; 17(1-2): 193-219.

[10] Łanczont M. Regional stratigraphy and lithology of the Carpathian loess deposits in Przemyśl environs. Bull Polish Acad Sci Earth Sci $1995 ; 43(1): 1-14$
[11] Połtowicz M. The Eastern borders of the Magdalenian Culture Range. Analecta Archaeologica Ressoviensia 2006; 1: 11-28.

[12] Schild R. The Site of Wilczyce. Conf. Papers „Studia interdyscyplinarne nad lessami - problemy metodyczne" (,Interdisciplinary studies on loesses - methodic problems"). Lublin UMCS 2006; pp. 81-83.

[13] Kusiak J. Kontekst stratygraficzny zastosowania różnych odmian metody termoluminescencyjnej w datowaniu lessów z terenu Polski południowo-wschodniej i Ukrainy północno-zachodniej (Stratigraphic context of the use of different varieties of thermoluminescence method in dating of loesses from southeastern Poland and north-western Ukraine). Annales UMCS, 2008; vol. B, 63: pp. 21-60.

[14] Mroczek P. Interpretacja paleogeograficzna cech mikromorfologicznych neoplejstoceńskich sekwencji lessowoglebowych (The paleogeographical interpretation of micromorphological features of the Neopleistocene loess-paleosol sequences). Lublin; Wydawnictwo UMCS 2008; ss 130.

[15] Mamakowa K, Starkel L. Stratigraphy of Late Glacial and Early Holocene alluvia at Podgrodzie on the Wisłoka-River (SE Poland). Studia Geomorphologica Carpatho-Balcanica 1977; 11: 101-10.

[16] Stankowski W, Nita M. Stratigraphy of Late Quaternary deposits and their neotectonic record in the Konin area, central Poalnd. Geol Quart 2004; 48: 23-34.

[17] Granoszewski W. Late Pleistocene vegetation history and climatic changes at Horoszki Duże, E Poland: a palaeobotanical study. Acta Palaeobotanica 2003; Supp. 4: 1-95.

[18] Willis KJ, van Andel TH. Trees or no trees? The environments of central and eastern Europe during the Last Glaciation. Quat Sci Rev 2004; 23: 2369-87.

[19] Latałowa M, Nalepka D. A study of the Late-Glacial and Holocene vegetational history of the Wolbrom area (Silesian- Cracovian Upland). Acta Palaeobotanica 1987; 27(1): 75-115.

[20] Nalepka D. Historia roślinności w dolinie Wisły od Krakowa po ujście Raby w późnym vistulianie i holocenie (Vegetation history in the Vistula River valley from Cracow to the Raba River mouth in the Late Vistulian and Holocene). In: Starkel L, Prokop P, Eds. Przemiany środowiska przyrodniczego Karpat (Changes of natural environment in the Carpathians). Conf. Papers, 20. IGiPZ, PAN Krakow 1994; pp. 19-32.

[21] Niedziałkowska E, Szczepanek K. Utwory pyłowe vistuliańskiego stożka Wisły w Kotlinie Oświęcimskiej (Silt deposits of the Vistulian fan of the Vistula River in the Oświęcim Basin). Studia Geomorph. Carp.-Balc. 1994; 27-28: pp. 29-44.

[22] Obidowicz A. A Late Glacial-Holocene history of the formation of vegetation belts in the Tatra Mts. Acta Palaeobotanica 1996; 36(2): 159-206.

[23] Matuszkiewicz JM. Zespoły leśne Polski (Forest associations in Poland). Warszawa, PWN 2002.

[24] Bratlund B. The faunal remains from Wilczyce. In: Valentin EB, Bratlund B, Eds. Recent Studies in the Final Palaeolithic of the European Plain. Åarhus: Jutland Archaeological Society 2002; pp. $101-7$. 